\title{
Keberadaan bakteri patogen pada sampel pangan jajanan anak sekolah dasar di Pulau Sapeken, Sumenep, Jawa Timur
}

\author{
The presences of pathogenic bacteria in snack for school children on Sapeken Island, \\ Sumenep, East Java \\ Ivani Dayanara*, Retno Kawuri, Dwi Ariani Yulihastuti \\ Program Studi Biologi, Fakultas Matematika dan Ilmu Pengetahuan Alam, Universitas Udayana, Jimbaran, Kuta Selatan, \\ Badung, Bali 80361 - Indonesia
}

Email: i.dayanara28@gmail.com

Diterima 16 Agustus 2019; Disetujui 10 Desember 2019

\section{INTISARI}

Pangan Jajanan Anak Sekolah (PJAS) adalah pangan yang ditemukan dan secara rutin dikonsumsi oleh anak-anak di lingkungan sekolah. Pangan yang baik dan sehat harus terbebas dari bahan-bahan berbahaya dan beracun, seperti cemaran mikroba, kimia, dan bahan lainnya. Pangan harus memenuhi persyaratan batas cemaran mikroba berdasarkan pengujian keamanan SNI (Standar Nasional Indonesia). Penyebab keracunan pangan yang masih menjadi masalah yang serius di berbagai negara termasuk Indonesia adalah bakteri patogen. Pulau Sapeken terletak di Desa Sapeken, Kecamatan Sapeken, Kabupaten Sumenep, Provinsi Jawa Timur. Tujuan penelitian untuk mengetahui keberadaan bakteri patogen pada sampel pangan jajanan anak sekolah di Pulau Sapeken. Metode yang digunakan yaitu Jumlah Perkiraan Terdekat (JPT) Escherichia coli, Uji Angka Bacillus sp., Uji Angka Staphylococcus sp., Identifikasi Salmonella, dan Total Plate Count (TPC). Hasil pengujian pada empek-empek JPT Escherichia coli di antaranya SD M $(9,9 \pm 3,8)$ MPN / g, SD $5(8,68 \pm 2,73) \mathrm{MPN} / \mathrm{g}$, SD IT $(5,08 \pm 0,66) \mathrm{MPN} / \mathrm{g}$, dan SD $4(4,26 \pm 2,44) \mathrm{MPN} / \mathrm{g}$. Hasil JPT $E$. coli pada empek-empek di SD 1 dan SD 2, serta JPT E. coli ojek disemua SD yaitu < 3 MPN / g. Hasil sampel pada empek-empek dan ojek pada semua SD untuk seluruh pengujian dengan parameter Angka Bacillus sp. adalah $<1 \times 10^{3}$, Angka Staphylococcus sp. adalah $<1 \times 10^{2}$, Identifikasi Salmonella adalah negatif, hasil TPC adalah < 1 x $10^{5}$ CFU / g. Kesimpulan pangan jajanan anak sekolah dasar (empek-empek dan ojek) di Pulau Sapeken tidak mengandung cemaran bakteri patogen Escherichia coli, Bacillus sp., Staphylococcus sp., Salmonella, dan Total Plate Count (TPC), kecuali pada pengujian JPT E. coli pada empek-empek di SD M, SD 5, SD IT, dan SD 4 melebihi batas SNI.

Kata kunci: bakteri patogen, pangan jajanan anak, standar keamanan.

\begin{abstract}
School children snacks are food that is found and routinely consumed by children in the school environment. Good and healthy food must be free from hazardous and toxic materials, such as microbial contamination, chemicals and other materials. The consumed food must meet the microbial contamination requirements based on SNI (Standar Nasional Indonesia) safety testing. Pathogenic bacteria still a serious problem in various countries including Indonesia, since they are capable of causing foodborne diseases. Sapeken Island is located in Sapeken Village, Sapeken District, Sumenep Regency, East Java Province. The purpose of the study was to determine the presence of pathogenic bacteria in samples of snacks for school children on Sapeken Island. The method used was the Most Probable Number (MPN) for Escherichia coli, Test Number of Bacillus sp., Test Number of Staphyllococcus sp., Identification of Salmonella, and Total Plate Count (TPC). The test results obtained in the MPN of Escherichia coli included SD M (9.9 \pm 3.8$)$ MPN / g, SD 5 $(8.68 \pm 2.73) \mathrm{MPN} / \mathrm{g}$, SD IT $(5.08 \pm 0.66) \mathrm{MPN} / \mathrm{g}$, and SD $4(4.26 \pm 2.44) \mathrm{MPN} / \mathrm{g}$ exceed the SNI limit.
\end{abstract}


The results of JPT E. coli in snack empek-empek at SD I and SD 2, and JPT E. coli ojek in all elementary schools is <3 MPN / g. The results of the empek-empek and ojek samples in all elementary schools for all tests with the parameter number Bacillus sp. is $<1 \times 10^{3}$, the number of Staphylococcus sp. is $<1 \times 10^{2}$, Salmonella identification is negative, TPC is $<1 \times 10^{5} \mathrm{CFU} / \mathrm{g}$. The conclusion of the study is snack for school children (empek-empek) and ojek on Sapeken Island does not contain contamination of pathogenic bacteria Escherichia coli, Bacillus sp., Staphylococcus sp., Salmonella identification, and TPC, except for the JPT E. coli test on empek empek in SD M, SD 5, SD IT and SD 4 that exceed SNI limits.

Key word: pathogenic bacteria, security standard, snacks for school children.

\section{PENDAHULUAN}

Pangan merupakan kebutuhan dasar manusia yang sangat berpengaruh terhadap eksistensi dan ketahanan hidup, baik dari segi kuantitas dan kualitas (BPOM RI, 2016). Pentingnya nilai gizi dalam pangan tergantung pada keamanan pangan yaitu Standar Nasional Indonesia yang diberlakukan. Informasi maupun data mengenai status dalam pangan olahan jajanan anak sekolah di Pulau Sapeken diperlukan untuk meningkatkan keamanan dan kualitas pangan.

Pulau Sapeken terletak di Desa Sapeken, Kecamatan Sapeken, Kabupaten Sumenep, Provinsi Jawa Timur, Indonesia. Pulau Sapeken secara geografis berbatasan dengan wilayah, yaitu perairan Kalimantan di sebelah Utara, perairan Bali di sebelah Selatan, perairan Sulawesi di sebelah Timur, serta laut Jawa dan Madura di sebelah Barat. Pulau Sepeken termasuk pulau yang penduduknya padat dengan KK berjumlah 2514 KK dan penduduk yang berjumlah 8211 jiwa. Tercatat sebanyak \pm 3923 jiwa penduduk berusia $0-25$ tahun. Pulau Sapeken memiliki 6 Sekolah Dasar (SD) dengan jumlah keseluruhan ada 914 siswa (Data Monografi Desa Sapeken, 2018). Tingginya jumlah penduduk usia anak sekolah ini menuntut untuk mendapatkan hak dalam pengawasan keamanan pangan dan perlindungan konsumen.

Menurut Arisanti et al. (2018) kejadian luar biasa (KLB) keracunan pangan di Indonesia periode 2000-2015 hasil penelitian dengan menggunakan pendekatan kajian sistematis dan kuantitatif menyebutkan bahwa KLB semakin meningkat setiap tahunnya. Keracunan pangan sebesar $60 \%$ diduga disebabkan oleh bakteri, tanpa dibuktikan dengan hasil uji laboratorium bahwa penyebab KLB terjadi karena bakteri. Bakteri patogen penyebab tertinggi dalam kasus keracunan pangan diantaranya Escherichia coli, Bacillus cereus, Staphylococcus sp., Salmonella. Kasus area keracunan pangan terbanyak terjadi di rumah tinggal, sekolah, dan pabrik. Penyebab keracunan pangan terbanyak terdapat pada jenis makanan rumah tangga, makanan jasa boga, dan olahan pangan jajanan. Kejadian luar biasa terbanyak terjadi di masakan rumah tangga, dan kematian tertinggi disebabkan makan makanan olahan industri rumah tangga.

Berdasarkan latar belakang di atas, maka dilakukan penelitian untuk mengkaji tentang keberadaan bakteri patogen dalam jajanan yang sering dikonsumsi anak pada sekolah dasar di Pulau Sapeken. Hal ini berdasarkan Kriteria Mikrobiologi dalam Pangan Olahan dalam Peraturan Kepala Badan Pengawas Obat dan Makanan Republik Indonesia Nomor 16 Tahun 2016, yang sesuai dengan Peraturan Kepala Badan Pengawas Obat dan Makanan Republik Indonesia Nomor 24 Tahun 2015 Tentang Pedoman Pengembangan Desa Pangan Aman.

\section{MATERI DAN METODE}

\section{Metode pengumpulan data}

\section{Waktu dan tempat penelitian}

Waktu penelitian dilakukan dari Bulan Desember 2018 sampai dengan Bulan Februari 2019. Pengujian terhadap keberadaan bakteri patogen Jumlah Perkiraan Terdekat (JPT) Escherichia coli, Angka Bacillus sp., Angka Staphylococcus sp., Identifikasi Salmonella, dan Total Plate Count (TPC) dalam sampel pangan 
jajanan anak sekolah dasar Pulau Sapeken dilakukan di Laboratorium Mikrobiologi Program Studi Biologi Fakultas Matematika dan Ilmu Pengetahuan Alam Universitas Udayana, Bukit Jimbaran, Bali. Pengujian identifikasi spesies bakteri dilakukan di Laboratorium Kesehatan Daerah (Kota Denpasar), Provinsi Bali.

\section{Pelaksanaan penelitian}

\section{Persiapan sampel}

Penanganan sampel dilakukan dengan memilih 2 jenis makanan yaitu ojek dan empek-empek di setiap sekolah dasar (SDN 1 Sapeken, SDN 2 Sapeken, SDN 4 Sapeken, SDN 5 Sapeken, SD IT Sapeken, dan SD M Sapeken). Sampel diperoleh dengan membeli jajanan langsung dari para penjual. Setiap jenis sampel dibungkus ke dalam plastik steril, diberi keterangan, dan dimasukkan ke dalam cooler box merk Marina aseptik. Sampel pangan masing-masing ditimbang sebanyak $\pm 40 \mathrm{~g}$ dan dimasukkan ke dalam botol plastik steril, diberi keterangan, dan dipindahkan ke dalam nitrogen cair box. Sampel kemudian diangkut ke kapal dan dibawa dari Pelabuhan Sapeken menuju Pelabuhan Singaraja tujuan Bali untuk dilakukan pengujian.

\section{Alat dan Bahan Penelitian}

Alat yang digunakan dalam penelitian ini diantaranya Erlemeyer, vortex, gelas Beaker, cawan Petri, tabung Durham, tabung reaksi, dan alat gelas lainnya. Bahan yang digunakan dalam penelitian ini yaitu Pepton Dilution Fluid (PDF), Lactose Broth double concentration, Lactose Broth single concentration, Brilliant Green Bile Broth (BGBB), Eosin Methylene Blue Agar (EMBA), Agar Darah (Blood Agar), Mannitol Salt Agar (MSA), Buffered Peptone Water (BPW), Salmonella Shigella Agar (SSA), Nutrient Agar (NA), Plate Count Agar (PCA), pewarna kristal violet, iodin, alkohol 95\%, dan pewarna safranin.

\section{Pengujian Jumlah Perkiraan Terdekat (JPT) Escherichia coli}

Sampel ditimbang $10 \mathrm{~g}$ secara aseptik dan dimasukkan ke dalam botol kaca berisi 90 mL PDF, kemudian dihomogenkan dengan vortex selama 1 menit sehingga diperoleh dengan pengenceran $10^{-1}$ sampai $10^{-2}$. Hasil pengenceran $10^{-2}$ diinokulasikan ke 3 seri tabung yang dilengkapi tabung Durham pada media Lactose Broth double concentration dan Lactose Broth single concentration. Sampel diinkubasi pada suhu $37^{\circ} \mathrm{C}$ selama 24 - 48 jam, dan diamati terbentuknya gas serta kekeruhan pada setiap tabung. Selanjutnya, uji hasil positif diinokulasikan ke dalam tabung reaksi yang dilengkapi tabung Durham pada media BGBB, dan diinkubasi pada suhu $37^{\circ} \mathrm{C}$ selama $24-48$ jam. Dilakukan pengamatan terhadap uji penegasan dengan hasil positif terbentuk gas dan kekeruhan pada setiap tabung. Hasil positif dari biakan BGBB selanjutnya dilakukan streak di media EMBA, kemudian diinkubasi suhu $37^{\circ} \mathrm{C}$ selama $48 \pm 2$ jam. Hasil positif pada media EMBA akan terbentuk koloni berwarna hijau metalik. Terakhir, dilakukan pewarnaan Gram, dihitung koloni E. coli, dan dicocokkan pada Tabel MPN seri 333 tabung menurut Formula Thomas.

\section{Pengujian Angka Bacillus sp.}

Ditimbang secara aseptik $10 \mathrm{~g}$ sampel dan dimasukkan ke dalam botol kaca berisi $90 \mathrm{~mL}$ Peptone Dilution Fluid (PDF). Sampel dihomogenkan dengan menggunakan vortex selama 1 menit. $1 \mathrm{~mL}$ hasil pengenceran $10^{-1}$ sampel dipipet dan dilakukan inokulasi dengan metode streak plate pada media Agar Darah (Blood Agar). Sampel selanjutnya diinkubasi dengan posisi cawan Petri dibalik yang dilakukan di suhu $36^{\circ} \mathrm{C} \pm 1{ }^{\circ} \mathrm{C}$ selama 48 jam. Diamati koloni yang tumbuh pada media Agar Darah (Blood Agar). Dilakukan reisolasi pada koloni tumbuh yang diduga Bacillus sp. Hasil diamati dengan melihat ciri-ciri koloni spesifik yang tumbuh pada media Agar Darah (Blood Agar) yaitu berwarna abu-abu dengan bentuk tepi koloni tidak rata dan sedikit bergelombang. Dilakukan pewarnaan Gram yang diduga koloni Bacillus sp., dan dihitung koloni spesifik Bacillus sp. Terakhir, diidentifikasi dengan BBL Crystal.

\section{Pengujian Angka Staphylococcus sp.}

Disiapkan 10 g sampel dengan cara aseptik dimasukkan ke dalam botol kaca yang berisi $90 \mathrm{~mL}$ Peptone Dilution Fluid (PDF), agar diperoleh hasil 
pengenceran $10^{-1}$ yang homogen digunakan vortex selama 1 menit. Dipipet $1 \mathrm{~mL}$ hasil pengenceran $10^{-}$ 1 dan diinokulasikan menggunakan metode pour plate pada media MSA. Kemudian diinkubasi pada suhu $37^{\circ} \mathrm{C}$ selama 48 jam dengan posisi cawan Petri dibalik. Koloni yang tumbuh kemudian diamati, bakteri yang diduga Stapylococcus sp. dilakukan rekultur. Selanjutnya, posisi cawan Petri secara terbalik diinkubasi pada suhu $37^{\circ} \mathrm{C}$ selama 24 jam. Bakteri spesifik pada media Mannitol Salt Agar ditandai dengan ciri-ciri koloni dan medianya berwarna kuning, dengan ukuran koloni kecil sampai dengan sedang, permukaan halus. Koloni Staphylococcus sp. selanjutnya dipilih untuk dilakukan pewarnaan Gram. Terakhir, Staphylococcus sp. yang sudah dikonfirmasi pewarnaan Gram dihitung dinyatakan sebagai angka Staphylococcus sp.

\section{Pengujian Identifikasi Salmonella}

Disiapkan secara aseptik $10 \mathrm{~g}$ sampel yang sudah berisikan $90 \mathrm{~mL}$ Buffered Peptone Water (BPW) dalam botol kaca. Sampel dihomogenkan menggunakan vortex selama 1 menit, dan di masukkan ke dalam inkubator suhu $37^{\circ} \mathrm{C} \pm 1{ }^{\circ} \mathrm{C}$ selama $18 \pm 2$ jam. Sampel $1 \mathrm{~mL}$ hasil pengenceran $10^{-1}$ diinokulasikan menggunakan metode pour plate pada media SSA. Sampel dalam cawan Petri dengan posisi dibalik selanjutnya dimasukkan ke inkubator suhu $37^{\circ} \mathrm{C} \pm 1{ }^{\circ} \mathrm{C}$ selama $45 \pm 48$ jam. Diamati koloni spesifik yang tumbuh pada media Salmonella Shigella Agar yaitu koloni transparan dengan warna hitam dibagian tengahnya, berukuran kecil-kecil, berbentuk pipih, halus dan bulat.

\section{Pengujian Total Plate Count (TPC)}

Homogenisasi sampel menggunakan vortex selanjutnya dilakukan selama 1 menit. Ditimbang 10 g sampel dengan cara aseptik yang sudah berisikan $90 \mathrm{~mL}$ Peptone Dilution Fluid (PDF) dalam botol kaca. Dilakukan pengenceran pada hasil pengenceran $10^{-1}$ dan dibuat hingga $10^{-5}$. Setiap sampel diinokulasikan sebanyak $1 \mathrm{~mL}$ dari hasil pengenceran $10^{-1}$ sampai $10^{-5}$, dimasukkan ke cawan Petri steril, dan media PCA dituangkan sebanyak $\pm 20 \mathrm{~mL}$. Cawan Petri digoyanggoyangkan untuk menghomogenkan sampel dan media. Kemudian, dengan posisi terbalik cawan Petri diinkubasi suhu $36{ }^{\circ} \mathrm{C} \pm 1{ }^{\circ} \mathrm{C}$ selama 24 jam. Diamati pertumbuhan koloni dan jumlah koloni yang tumbuh dihitung. Perhitungan cawan Petri didapat dari media yang ditumbuhi $25-250$ koloni.

\section{Variabel Penelitian}

Variabel dalam penelitian ini terdiri dari variabel bebas dan variabel terikat. Variabel bebas adalah keberadaan bakteri patogen pada sampel pangan jajanan anak sekolah dasar di pulau Sapeken, Sumenep, Jawa Timur. Sedangkan, variabel terikat adalah jumlah bakteri patogen Escherichia coli, Bacillus sp., Staphylococcus sp., Identifikasi Salmonella, dan Total Plate Count (TPC).

\section{Rancangan Penelitian}

Penelitian dilakukan secara eksplorasi dan uji laboratorium. Keberadaan bakteri patogen dilakukan uji sampel pangan jajanan anak sekolah dasar di Sapeken, Sumenep, Jawa Timur dengan metode Jumlah Perkiraan Terdekat (JPT) Escherichia coli, Angka Bacillus sp., Angka Staphylococcus sp., Identifikasi Salmonella, dan Total Plate Count (TPC). Pengujian keberadaan bakteri patogen menggunakan RAL (Rancangan Acak Lengkap) dengan 5 kali ulangan berdasarkan rumus:

$$
(\mathrm{n}-1)(\mathrm{t}-1) \geq 15
$$

Keterangan :

$\mathrm{n}$ : jumlah pengulangan

t : jumlah perlakuan

(Federer, 1999).

\section{Metode Pengumpulan Data}

Metode pengumpulan data dilakukan dengan cara eksplorasi dan uji laboratorium, yaitu data diperoleh langsung dari sampel jajanan yang diambil di lapangan dan hasil pengujian sampel pangan jajanan anak sekolah dasar di Pulau Sapeken.

\section{Metode Pengolahan Data}

Metode pengolahan data dilakukan secara kuantitatif menggunakan aplikasi Microsoft Excel 
2013. Hasil penelitian diuraikan secara terperinci dan disajikan dalam bentuk data tabel, diagram, gambar, dan tulisan.

\section{HASIL}

Hasil uji keberadaan bakteri patogen Jumlah Perkiraan Terdekat (JPT) Escherichia coli, Angka Bacillus sp., Angka Staphylococcus sp., Identifikasi Salmonella, dan Total Plate Count (TPC) pada 2 jenis sampel pangan jajanan (ojek dan empekempek) yang diambil di enam sekolah dasar di

Pulau Sapeken, Sumenep, Jawa Timur, dengan 5 kali ulangan yang dilakukan, tersaji dibawah ini.

\section{Jumlah Perkiraan Terdekat (JPT) Escherichia coli pada pangan jajanan anak sekolah (PJAS)}

Berdasarkan penelitian yang telah dilakukan didapatkan hasil pangan jajanan anak sekolah dasar di Pulau Sapeken positif mengandung E. coli. Media EMBA yang positif ditandai dengan ciri-ciri koloni E. coli yang tumbuh yaitu berukuran sedang, permukaan halus, berbentuk keping, berwarna hijau metalik, dan sudah dikonfirmasi dengan pewarnaan Gram (Gambar 1).

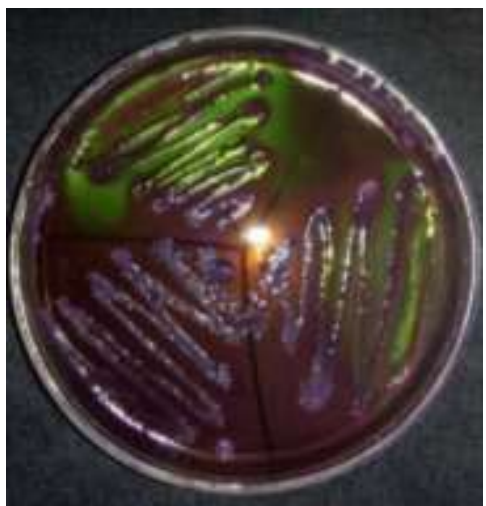

(a)

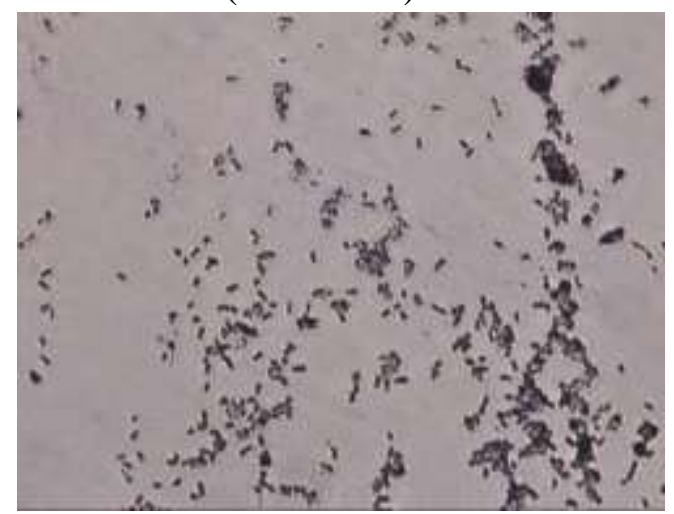

(b)

Gambar 1. Bakteri E. coli (a) Koloni bakteri Escherichia coli berwarna hijau metalik yang tumbuh pada media EMBA; dan (b)Pewarnaan sel bakteri Escherichia coli berbentuk batang pendek Perbesaran 10x100

Hasil pengujian Jumlah Perkiraan Terdekat (JPT) E. coli pada pangan jajanan anak sekolah dasar di Pulau Sapeken menunjukkan bahwa 4 dari 12 sampel terdapat E. coli melebihi batas SNI yaitu
< 3 MPN / g yang sudah ditetapkan (Gambar 2). Nilai rata-rata \pm standar deviasi hasil JPT $E$. coli berkisar antara $(0,08 \pm 0,18) \mathrm{MPN} / \mathrm{g}$ sampai $(9,9 \pm$ 3,8) MPN / g.

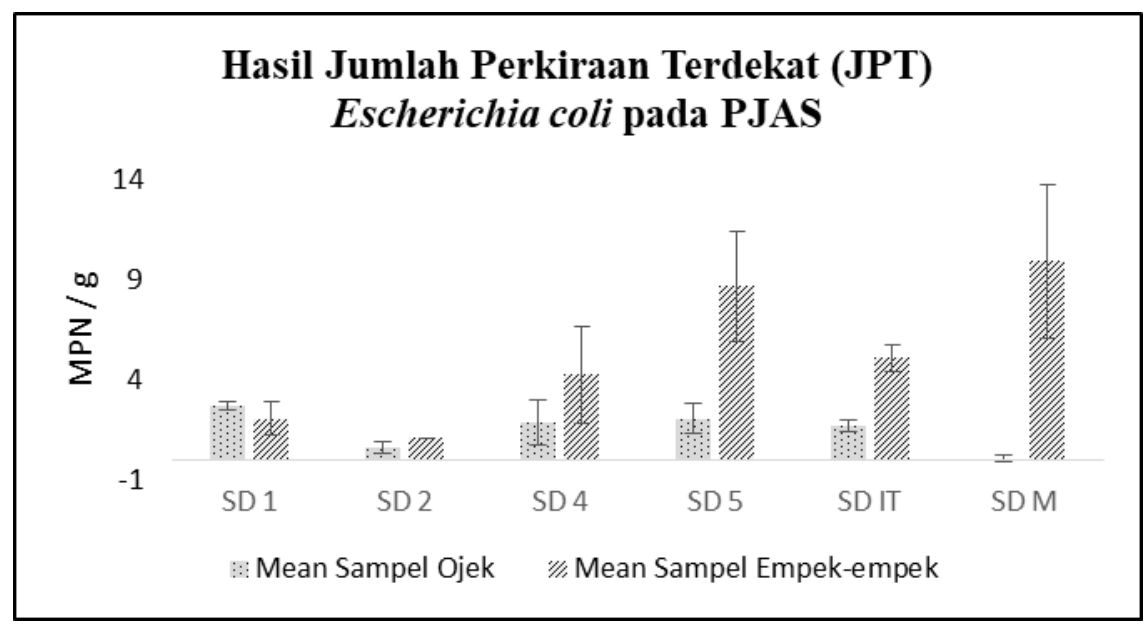

Gambar 2. Hasil Jumlah Perkiraan Terdekat (JPT) Escherichia coli pada sampel pangan jajanan anak sekolah dasar di Pulau Sapeken 


\section{Angka Bacillus sp. pada pangan jajanan anak sekolah (PJAS)}

Hasil isolasi tidak ditemukan bakteri Bacillus sp. diseluruh sampel yang diujikan, tetapi pada media Blood Agar (Gambar 3a) tumbuh koloni berukuran kecil-kecil berwarna abu-abu. Peneliti tertarik untuk melanjutkan identifikasi bakteri yang tumbuh pada media tersebut. Hasil pewarnaan
Gram ditemukan yaitu sel bakteri berbentuk kokus (Gambar 3c). Identifikasi dilakukan dengan menggunakan BBL Crystal (Becton Dickinson Microbiology Systems, Cockeysville, Md) dilakukan di Laboratorium Daerah Kota Denpasar. Hasil sampel teridentifikasi sebagai Staphylococcus lentus

(Gambar

$3)$.

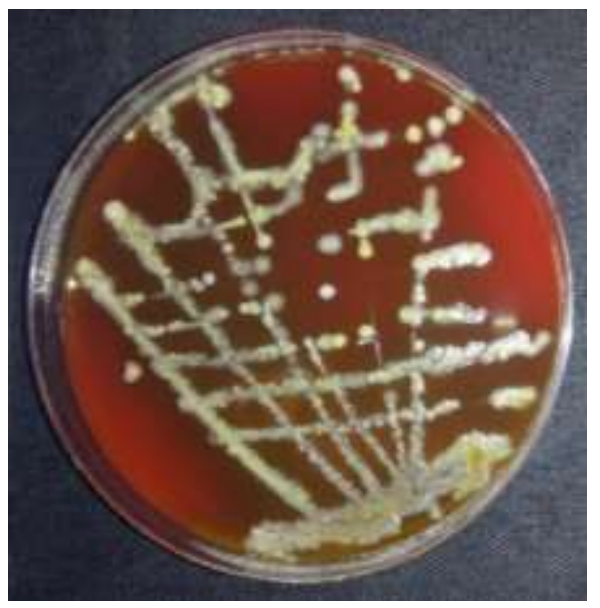

(a)

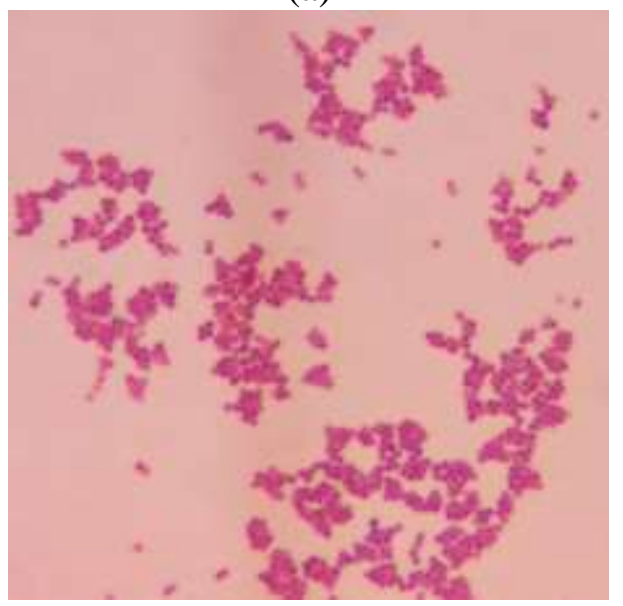

(c)

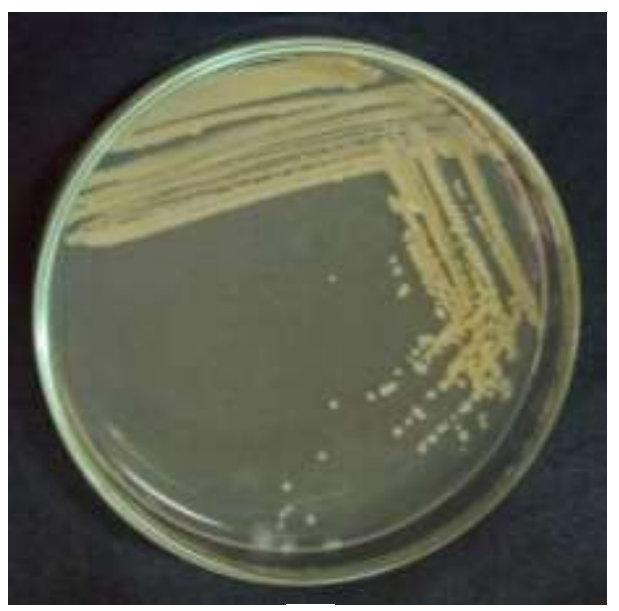

(b)

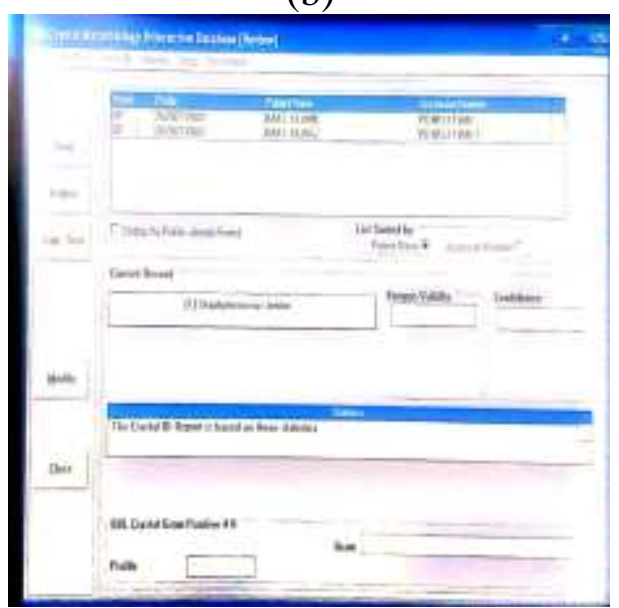

(d)

Gambar 3. Hasil identifikasi bakteri pada pangan jajanan anak sekolah (a) Koloni yang diduga bakteri Bacillus sp. berwarna abu-abu tumbuh pada media Blood Agar; (b) Hasil reisolasi koloni yang diduga ditumbuhkan pada media NA; (c) Pewarnaan sel bakteri yang ditemukan berbentuk kokus Perbesaran 10x100; dan (d) Hasil identifikasi Staphylococcus lentus menggunakan BBL Crystal

\section{Angka Staphylococcus sp. pada pangan jajanan anak sekolah (PJAS)}

Berdasarkan pengujian Angka Staphylococcus sp. didapatkan hasil positif bakteri Staphylococcus sp. yang ditandai pada media MSA yaitu tumbuh koloni berukuran kecil sampai sedang, permukaan halus, koloni berwarna kuning dengan media yang berubah menjadi warna kuning, dan sudah dikonfirmasi dengan dilakukan pewarnaan Gram 
pada sampel yang diduga tumbuh koloni Staphylococcus

sp. $\quad$ Gambar

4).

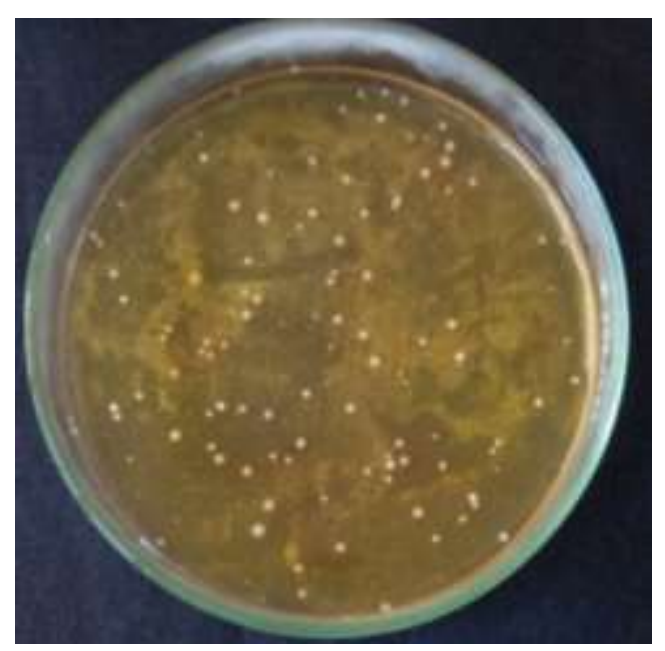

(a)

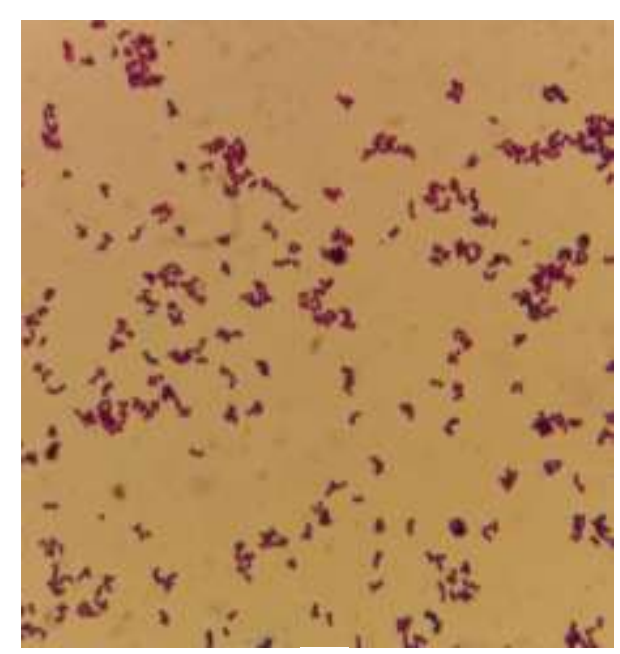

(b)

Gambar 4. Hasil identifikasi bakteri pada pangan jajanan anak sekolah (a) Koloni bakteri Staphylococcus sp. berwarna kuning dan media MSA yang berubah menjadi warna kuning; dan (b) Pewarnaan sel bakteri Staphylococcus sp. berbentuk kokus berkelompok Perbesaran 10x100

Sampel yang sudah dilakukan pengujian ditemukan hasil sebanyak 7 dari 12 sampel sesuai dengan ciri-ciri koloni Staphylococcus sp. Angka bakteri Staphylococcus sp. yang terkandung dalam pangan jajanan anak sekolah dasar di Pulau Sapeken (Gambar 5) diperoleh nilai rata-rata \pm standar deviasi, diantaranya pada sampel PJAS ojek SD IT $(7,4 \pm 1,14) \times 10^{1}$ koloni / g, SD $2(6 \pm 1,58)$ x $10^{1}$ koloni / g, dan SD $1(2,6 \pm 0,55)$ x $10^{1}$ koloni / $\mathrm{g}$, serta untuk hasil sampel PJAS empek-empek yaitu dari SD $5(2 \pm 0,71) \times 10^{1}$ koloni / g, SD $4(1,6$ $\pm 0,55) \times 10^{1}$ koloni / g, SD M $(1,2 \pm 0,45) \times 10^{1}$ koloni / g, dan SD $2(0,2 \pm 0,45) \times 10^{1}$ koloni / g. Berdasarkan hasil pengujian dinyatakan masih memenuhi syarat untuk dikonsumsi jika tidak melebihi batas SNI yaitu 1 x $10^{2}$ koloni / g.

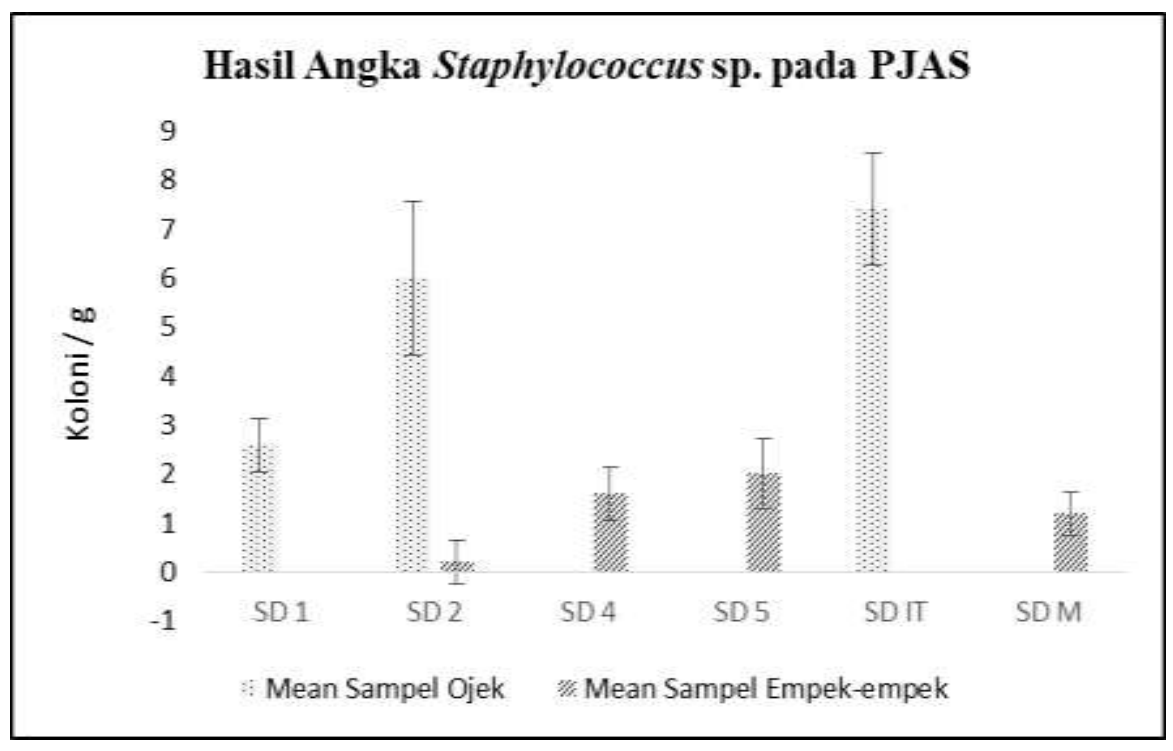

Gambar 5. Hasil Angka Staphylococcus sp. $\left(10^{1}\right)$ pada sampel pangan jajanan anak sekolah dasar di Pulau Sapeken 


\section{Identifikasi Salmonella pada pangan jajanan anak sekolah (PJAS)}

Pengujian Identifikasi Salmonella yang positif bakteri Salmonella sp. ditandai dengan tumbuhnya koloni pada media SSA yaitu koloni berukuran kecil-kecil, permukaan halus, berbentuk bulat dengan tepi pipih, berwarna transparan dengan warna hitam dibagian tengah. Berdasarkan pengujian yang dilakukan terhadap sampel tidak ditemukan koloni yang tumbuh pada media SSA seperti ciri-ciri koloni Salmonella sp. sehingga tidak dilakukan uji konfirmasi (Gambar 6). Hasil pengujian Identifikasi Salmonella pada pangan jajanan anak sekolah dasar di Pulau Sapeken (Tabel 1) dinyatakan memenuhi syarat untuk dikonsumsi karena hasil menunjukkan negatif Salmonella sp.

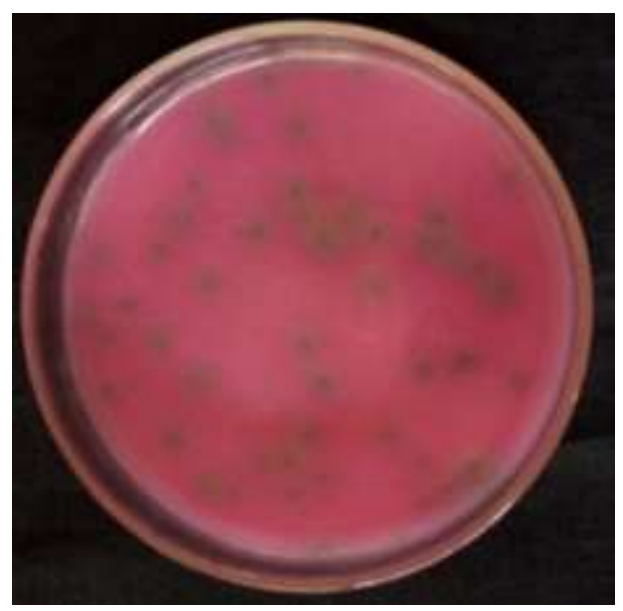

Gambar 6. Tidak ada koloni yang diduga Salmonella sp. tumbuh pada media SSA

Tabel 1. Hasil Uji Identifikasi bakteri Salmonella yang diujikan dari 6 sampel empek-empek dan 6 sampel Ojek dengan 5 kali pengulangan didapatkan bahwa tidak ada Salmonella yang tumbuh pada media SSA sehingga seluruh sampel dinyatakan Negatif Salmonella sesuai syarat SNI yaitu memenuhi syarat (MS) untuk dikonsumsi

\begin{tabular}{llllll}
\hline \multirow{2}{*}{ No. } & Sampel & \multicolumn{2}{c}{ Hasil Identifikasi Salmonella } & Syarat SNI & Keterangan \\
\cline { 3 - 4 } & & $\begin{array}{c}\text { Sampel } \\
\text { Ojek }\end{array}$ & $\begin{array}{c}\text { Sampel } \\
\text { Empek-empek }\end{array}$ & & \\
\hline 1. & SD 1 & Negatif & Negatif & Negatif & MS \\
2. & SD 2 & Negatif & Negatif & Negatif & MS \\
3. & SD 4 & Negatif & Negatif & Negatif & MS \\
4. & SD 5 & Negatif & Negatif & Negatif & MS \\
5. & SD IT & Negatif & Negatif & Negatif & MS \\
6. & SD M & Negatif & Negatif & Negatif & MS \\
\hline
\end{tabular}

\section{Total Plate Count (TPC) pada pangan jajanan anak sekolah (PJAS)}

Total Plate Count pada PJAS berdasarkan hasil bakteri yang tumbuh dalam media PCA dapat dihitung sebagai 1 sel koloni bakteri (Gambar 7). Total Plate Count pada pengujian sampel pangan jajanan anak sekolah dasar di Pulau Sapeken (Tabel 2) diperoleh hasil < 1 x $10^{5} \mathrm{CFU} \mathrm{/} \mathrm{g.} \mathrm{Jika}$ dibandingkan dengan nilai SNI, maka hasil pengujian pada sampel dinyatakan memenuhi syarat aman untuk dikonsumsi. 


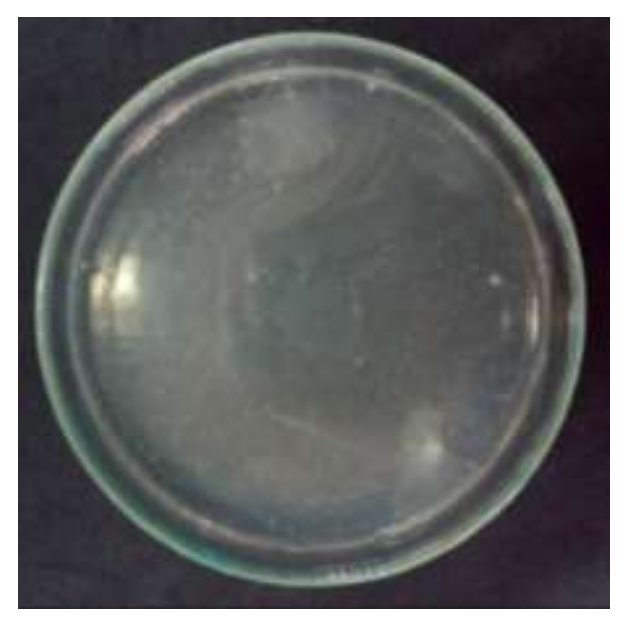

Gambar 7. Koloni bakteri pengenceran $10^{2}$ yang tumbuh pada media PCA

Tabel 2. Hasil Total Plate Count (TPC) pada media PCA didapatkan seluruh sampel yang diujikan dengan 5 kali pengulangan berada dibawah syarat SNI yaitu < 1 x 105 CFU / g sehingga memenuhi syarat (MS) untuk dikonsumsi

\begin{tabular}{lccccc}
\hline & & \multicolumn{2}{c}{ Hasil Rata - rata \pm Standar Deviasi PJAS } \\
CFU/g & $\begin{array}{c}\text { Syarat SNI } \\
\text { CFU/g }\end{array}$ & Keterangan \\
\cline { 3 - 4 } & So. & $\begin{array}{c}\text { Sampel } \\
\text { Ojek }\end{array}$ & $\begin{array}{c}\text { Sampel } \\
\text { Empek-empek }\end{array}$ & \\
\hline 1. & SD 1 & $(4,2 \pm 0,3) \times 10^{2}$ & $(4,04 \pm 0,37) \times 10^{4}$ & $<1 \times 10^{5}$ & MS \\
2. & SD 2 & $(1,05 \pm 0,05) \times 10^{3}$ & $(3,65 \pm 0,29) \times 10^{3}$ & $<1 \times 10^{5}$ & MS \\
3. & SD 4 & $(3,22 \pm 0,31) \times 10^{2}$ & $(9,95 \pm 0,21) \times 10^{4}$ & $<1 \times 10^{5}$ & MS \\
4. & SD 5 & $(6,21 \pm 0,4) \times 10^{2}$ & $(4,32 \pm 0,35) \times 10^{3}$ & $<1 \times 10^{5}$ & MS \\
5. & SD IT & $(5,62 \pm 0,21) \times 10^{2}$ & $(4,05 \pm 0,15) \times 10^{3}$ & $<1 \times 10^{5}$ & MS \\
6. & SD M & $(4,5 \pm 0,7) \times 10^{1}$ & $(4,01 \pm 0,65) \times 10^{3}$ & $<1 \times 10^{5}$ & MS \\
\hline
\end{tabular}

\section{PEMBAHASAN}

Nilai Jumlah Perkiraan Terdekat Escherichia coli yang melebihi batas SNI pada penelitian pangan jajanan anak (empek-empek) di sekolah dasar di Pulau Sapeken secara berurutan terjadi di SD M $(9,9 \pm 3,8) \mathrm{MPN} / \mathrm{g}, \mathrm{SD} 5(8,68 \pm 2,73) \mathrm{MPN}$ / g, SD IT $(5,08 \pm 0,66) \mathrm{MPN} / \mathrm{g}$, dan SD 4 (4,26 \pm 2,44) MPN / g. Hal ini menunjukkan bahwa hasil tidak memenuhi syarat keamanan pangan untuk dikonsumsi karena bisa menjadi agensia penyebab kasus keracunan pangan. Escherichia coli menjadi salah satu mikroorganisme indikator sanitasi. Menurut Adams dan Motoarjemi (2003) bakteri patogen E. coli yang mengkontaminasi pangan bisa terjadi karena kurangnya perhatian terhadap sanitasi, baik yang berasal dari bahan pangan jajanan, penjamah jajanan, tempat penjualan, dan peralatan yang digunakan, serta peralatan yang digunakan kembali tanpa dicuci bersih, terutama peralatan yang digunakan untuk makanan matang atau siap santap.

Patogen penyebab penyakit yang mengkontaminasi pangan dapat menjadi ancaman yang serius. Sesuai penelitian yang telah dilakukan oleh Riyanto dan Asep (2012) mengenai faktorfaktor yang dapat mempengaruhi kandungan $E$. coli di dalam makanan yaitu terdapat hubungan bermakna antara $E$. coli dengan pengolahan makanan yang bersih, peralatan, bahan, dan sarana penjualan makanan jajanan di sekolah dasar. Menurut Mudey et al. (2010) pengetahuan dan perilaku sangat berpengaruh terhadap kualitas makanan dan tingkat risiko kontaminasi akibat bakteri. Penerapan personal higyene penjamah yang baik oleh responden masih mengandung $E$. coli di 
dalam makanannya dapat terjadi karena saat proses penyimpanan makanan tidak tepat. Makanan yang disimpan di ruang terbuka rentan terkontaminasi $E$. coli menjadi 2 kali lipat.

Bakteri Bacillus sp. tidak ditemukan pada seluruh sampel yang diuji. Hasil identifikasi menunjukkan ditemukan bakteri Staphylococcus lentus. Menurut Shaker et al. (2018) S. lentus adalah bakteri patogenik dan mempunyai kemampuan menyebabkan penyakit dan resisten terhadap antibiotik. Staphylococcus lentus ditemukan dibeberapa ruang operasi di tiga rumah sakit di Iraq. Mazal dan Sleger (2010) mengatakan Staphylococcus lentus ditemukan pada hewan namun jarang menginfeksi manusia, dari 72 kasus yang diteliti selama 9 tahun, ditemukan 20 kasus $S$. lentus yang mampu menginfeksi manusia, dan ditemukan dari urin, cairan lambung, darah, dan lainnya dari luka. Gejala yang ditimbulkan oleh $S$. lentus yaitu demam, pusing, dan leukositosis.

Bakteri Staphylococcus sp. yang terkandung dalam pangan jajanan harus sesuai SNI dalam Peraturan Kepala Badan Pengawas Obat dan Makanan Republik Indonesia Nomor 16 Tahun 2016 yaitu < 1 x 10 2 koloni / g. Pengujian Angka Staphylococcus sp. yang sudah dilakukan terhadap sampel pangan jajanan anak sekolah di Pulau Sapeken memberikan hasil bahwa 7 dari 12 sampel mengandung Staphylococcus sp. Meskipun hasil diketahui mengandung bakteri Staphylococcus sp., tetapi hasil masih berada di bawah SNI yang telah ditetapkan pemerintah sehingga aman untuk dikonsumsi. Menurut Okolie et al. (2012) walaupun tidak selalu menimbulkan penyakit, namun adanya bakteri Staphylococcus sp. akan mempengaruhi nilai gizi makanan.

Menurut Pelczar et al. (2014) keracunan Staphylococcus sp. disebabkan ketika konsumen mengkonsumsi makanan yang telah terkontaminasi oleh bakteri dalam jumlah berlebih dan bakteri tersebut mengeluarkan toksin yang tidak bisa ditolerir oleh tubuh. Keracunan yang disebabkan adanya Staphylococcus sp. dalam makanan berhubungan erat dengan kebersihan penjamah dalam mengolah, penyimpanan dan menyajikan makanan menjadi faktor penyebab utama, karena berhubungan dengan keberadaan bakteri yang berada di permukaan kulit dan selaput lendir.
Staphylococcus sp. yang menghasilkan enterotoksin dalam makanan dapat menyebabkan gastroenteritis dan inflamasi pada saluran usus. Penelitian Pratama et al. (2016) menunjukkan tidak ada pengaruh nyata kondisi kemasan pangan terhadap $S$. aureus dalam pangan, sedangkan suhu dan lama penyimpanan, serta interaksi antar perlakuan memberikan pengaruh yang sangat nyata terhadap jumlah $S$. aureus pada pangan. Kondisi pertumbuhan $S$. aureus pada suhu $<7^{\circ} \mathrm{C}$ menjadi lambat disebabkan bukan suhu optimum pertumbuhan $S$. aureus.

Identifikasi Salmonella pada sampel pangan jajanan anak sekolah dasar di Pulau Sapeken berdasarkan Tabel 4.1. diketahui tidak didapatkan hasil yang positif. Ini sesuai dengan batas maksimum SNI Salmonella yaitu Negatif / 25 g dalam Peraturan Kepala Badan Pengawas Obat dan Makanan Republik Indonesia Nomor 16 Tahun 2016. Ziino et al. (2013) menyatakan daging dan daging olahan kemasan maupun non-kemasan di Teheran mengandung Salmonella sp., dan ditemukan adanya kontaminasi Salmonella sp. pada daging Kebab. Mengkonsumsi makanan yang mengandung Salmonella sp. dapat menyebabkan Salmonellosis. Salmonellosis adalah foodborne disease yang banyak ditemukan di berbagai negara terutama di negara berkembang (Kheyri et al., 2014).

Aerita et al. (2014) berdasarkan hasil penelitian di lapangan menyatakan terdapat hubungan antara sanitasi dengan kontaminasi Salmonella sp. Adanya Salmonella sp. terjadi karena terdapat keterikatan pangan dengan faktor penyebabnya, seperti sanitasi air dan peralatan yang meliputi penyediaan air bersih, penggantian air bilasan yang telah kotor, ketersediaan tempat pembuangan sampah dengan kondisi tertutup, dan peralatan pedagang yang bersih. Penelitian Kumalasari et al. (2017) menyatakan bahwa kontaminasi ditentukan dari jarak sumber pencemar, keberadaan vektor, tempat sampah. Kontaminasi Salmonella sp. erat hubungannya dengan jarak keberadaan sumber pencemar.

Pengujian Total Plate Count (TPC) bakteri pada sampel pangan jajanan anak sekolah jenis ojek dan empek-empek (Tabel 4.2) menunjukkan hasil yang berada di bawah SNI < 1 x $10^{5} \mathrm{CFU} \mathrm{/} \mathrm{g} \mathrm{sesuai}$ 
dengan Peraturan Nomor 16 Tahun 2016 yang telah ditetapkan Kepala Badan Pengawas Obat dan Makanan Republik Indonesia. Nilai rata-rata \pm standar deviasi tertinggi dan terendah pada sampel PJAS yaitu $(9,95 \pm 0,21) \times 10^{4} \mathrm{CFU} / \mathrm{g}$ dan $(4,5 \pm$ 0,7) x $10^{1} \mathrm{CFU} / \mathrm{g}$. Hasil penelitian Fauzi et al. (2017) bahwa ada pengaruh yang bermakna antara faktor kebersihan bahan dan pengolahan pangan dengan nilai TPC. Sehingga, dapat dikatakan bahwa faktor kebersihan bahan dan pengolahan pangan yang tidak memenuhi persyaratan dapat menjadi salah satu penyebab cemaran mikroba berdasarkan nilai TPC.

Andriyani et al. (2009) menyatakan terdapat hubungan antara cara pencucian alat dengan TPC dalam makanan. Penelitian Trisnaini (2012) melaporkan bakteri patogen yang berpotensi mengkontaminasi pangan terdapat pada beberapa tahap pengolahan, diantaranya tahap mendapatkan bahan makanan, tahap pembuatan dan pembentukan adonan, tahap perebusan, dan tahap penyajian. Sehingga perlu dilakukan pengendalian terhadap bahaya mikroorganisme dengan cara meningkatkan sanitasi alat dan lingkungan. Didukung oleh hasil penelitian Vitria et al. (2013) didapatkan hubungan yang signifikan antara cara pengolahan, cara pencucian peralatan, higiene penjamah, dan sanitasi peralatan dengan nilai TPC.

\section{SIMPULAN}

Pangan jajanan anak sekolah dasar (empekempek dan ojek) di Pulau Sapeken tidak mengandung cemaran bakteri patogen Escherichia coli, Bacillus sp., Staphylococcus sp., Salmonella, dan dan Total Plate Count (TPC) yang melebihi ambang batas SNI, kecuali pada pengujian JPT $E$. coli pada empek-empek di SD M, SD 5, SD IT, dan SD 4 yang melebihi batas SNI.

\section{UCAPAN TERIMA KASIH}

Penulis mengucapkan terima kasih kepada Ibu Dr. Ni Luh Suriani, S.Si., M.Si., Ibu Dra. Inna Narayani, M.Sc., Bapak Drs Yan Ramona, M.App.Sc., Ph.D. atas waktu, saran, dan masukannya.

\section{KEPUSTAKAAN}

Adams, M., dan Y. Motoarjemi. 2003. Dasar-Dasar Keamanan Makanan untuk Petugas Kesehatan. Jakarta: EGC.

Aerita, A. N., E. T. Pagewang, dan Maddiana. 2014. Hubungan higiene pedagang dan sanitasi dengan kontaminasi Salmonella pada daging ayam potong. Journal of Public Health 3(4) : 916.

Andriyani, A., I.M.A. Gunawan, dan J. Susilo. 2009. Efektifitas penurunan jumlah angka kuman alat makan dan efisiensi biaya yang digunakan pada metode pencucian alat makan pada rumah sakit Kota Surakarta. Journal of Gizi Klinik Indonesia 6 (1): 35-41.

Arisanti, R. R., I. Citra, dan A. W. Siswanto. 2018. Kontribusi agen dan faktor penyebab kejadian luar biasa keracunan pangan di Indonesia: Kajian Sistematis. Berita Kedokteran Masyarakat 34 (3): 99-106.

Data Monografi Desa Sapeken Kecamatan Sapeken Kabupaten Sumenep Tahun 2018. Kepala Desa Sapeken.

Fauzi, M., Miki, Rahmawati, dan R. Linda. 2017. Cemaran mikroba berdasarkan angka lempeng total dan angka paling mungkin koliform pada minuman air tebu (Saccharum officinarum) di Kota Pontianak. Protobiont. 6 (2): 8-15.

Federer, W. T. 1999. Statisticand Society: Data Collection and Interpretation. New York: Dekker.

Kheyri, A., M. Fakhernia, N. Haghighat-Afshar, H. Hassanzadazar, B. Kazemi-Ghoshchi, F. Zeynali, J. sadzadeh, F. Rahmanpour, and M. Bahmani. 2014. Microbial contamination of meat products produced in the factories of West Azerbaijan Province, North West of Iran. Global Veterinaria 12 (6): 796-802.

Kumalasari, C. R., P. Martini, dan Susiana. 2017. Hubungan sanitasi dengan status bakteriologi koliform dan keberadaan Salmonella sp. pada jajanan di Sekolah Dasar Wilayah Kecamatan 
Tembalang, Semarang. Aplikasi Tekhnologi Pangan 6(1): 19-22.

Mazal, C., and B. Sleger. 2010. Staphylococcus lentus. The Troublemaker. International Journal of Infectious Diseases 14(1): 397.

Mudey, A. B., N. Kesharwani, G.A. Mudey, R.C. Goyal, A.K. Dawale, and V. Wagh. 2010. Health status and personal hygiene among food handlers working at food establishment around a rural teaching hospital in Wardha District of Maharashtra, India. Global Journal of Health Science 2 (2): 198-206.

Okolie, N.P., E. Omonigbehin, O. A. Badru, and I.S. Akande. 2012. Isolation of pathogenic bacteria from some foods sold at selected private school in Akoka Area of Yaba Lagos. African journal of Food Science 6 (3): 65-69.

Pelczar, E.C.S. Michael, dan Chan. 2014. DasarDasar Mikrobiologi 2. Jakarta: UI-Press.

Peraturan Kepala Badan Pengawas Obat dan Makanan Republik Indonesia Nomor 24 Tahun 2015 Tentang Pedoman Pengembangan Desa Pangan Aman. Direktur Jenderal Peraturan Perundang-Undangan Kementerian Hukum dan Hak Asasi Manusia Republik Indonesia.

Peraturan Kepala Badan Pengawas Obat dan Makanan Republik Indonesia Nomor 21 Tahun 2016 Tentang Kategori Pangan. Kepala Badan Pengawas Obat dan Makanan Republik Indonesia.
Peraturan Kepala Badan Pengawas Obat dan Makanan Republik Indonesia Nomor 16 Tahun 2016 Tentang Kriteria Mikrobiologi Dalam Pangan Olahan. Kepala Badan Pengawas Obat dan Makanan Republik Indonesia.

Pratama, M., E. Warsiki, dan L. Haditjaroko. 2016. Kinerja label untuk memprediksi umur simpan pempek pada berbagai kondisi penyimpanan. Jurnal Teknologi Industri Pertanian 26(3): 321332.

Riyanto, A., dan D. A. Asep. 2012. Faktor yang mempengaruhi kandungan E. coli makanan jajanan SD di Wilayah Cimahi Selatan. Jurnal Majalah Kedokteran Bandung 44 (2): 77-82.

Shaker, M. N., T. A. Hmdan, and A. H. Issa. 2018. Isolation and diagnosis of Staphylococcus lentus from different operation theater hospitals. Scientific Journal of Medical Research. 2 (8): 177-181.

Trisnaini, I. 2012 Analisis bahaya titik kendali kritis proses pengolahan bola-bola daging di Instalasi Gizi Rumah Sakit. Jurnal Kesehatan Masyarakat Nasional 7(3): 131-138.

Vitria., E. Deny, dan Azrimaidaliza. 2013. Hubungan hygiene sanitasi dan cara pengolahan mie ayam dengan angka kuman di Kota Padang. Jurnal Kesehatan Masyarakat 7 (2): 75-81.

Ziino, G., G. Gurrera, and C. Beninati. 2013. Microbiological quality of Kebabs sold in Palermo and Messina. Italian Journal of Food Safety 2 (23): 77-80. 